\title{
EDUKASI SADAR VIRUS GAME ONLINE KEPADA MASYARAKAT AKADEMIK DI MADRASAH IBTIDAIYAH MUHAMMADIYAH MADURESO KECAMATAN KUWARASAN, KABUPATEN KEBUMEN
}

\author{
Azam Syukur Rahmatullah'1), Muhammad Azhar'1) \\ 1)Magister IImu Agama Islam, Universitas Muhammadiyah Yogyakarta, Yogyakarta, Indonesia \\ Corresponding author : Azam Syukur Rahmatullah \\ E-mail : azam.sy@umy.ac.id
}

Diterima 18 Februari 2021, Direvisi 03 Maret 2021, Disetujui 08 Maret 2021

\begin{abstract}
ABSTRAK
Virus game online menjadi salah satu momok yang menakutkan bagi para orang tua. Virus ini memiliki pengaruh yang menjadikan anak-anak kecanduan dimana hal tersebut mengarah pada fase merusak dan menenggelamkan masa depan anak. Oleh karenanya upaya-upaya pencegahan dan peminimalisiran perilaku candu game online harus diberdayakan sejak dini, dengan diadakannya program-program kegiatan berbasis pendidikan dan pencegahan virus game online. Program kemitraan masyarakat dilaksanakan di madrasah ibtidaiyah dikarenakan pencegahan dan pemahaman sejak dini kepada para peserta didik di level dasar akan semakin baik. Pengabdian Kemitraan Masyarakat yang berkaitan dengan pendidikan sadar dini terkait adanya virus game online dilaksanakan di madrasah Ibtidaiyah Madureso, Kecamatan Kuwarasan Kabupaten Kebumen.. Pengabdian tersebut berupa: Pertama,Sosialisasi kepada para guru/asatidz terkait pendidikan sadar virus game online yang berjumlah 25 orang. Kedua, memberi penyadaran dan pemahaman tentang virus game online dengan mendongeng kepada siswa kelas IV sampai kelas VI. Ketiga, mengadakan lomba poster bertemakan bebas virus game online bagi para peserta didik dan Keempat, membuat slogan-slogan anti virus game online bagi para peserta didik. Harapannya, dengan adanya pengabdian kemitraan masyarakat ini, Ibtidaiyah Madureso Kecamatan Kuwarasan, Kabupaten Kebumen akan benar-benar terbebas dari perilaku siswa didik yang mengarah pada kecanduan game online.
\end{abstract}

Kata kunci: game online; pengabdian kemitraan masyarakat; madrasah ibtidaiyah muhammadiyah madureso kuwarasan kebumen

\begin{abstract}
Online game viruses have become a frightening specter for parents. This virus has an effect that makes children addicted which leads to a destructive phase and drowns out the child's future. Efforts to prevent and minimize the addictive behavior of online games must be empowered from early stage, with the implementation of educational-based activity programs and online game virus prevention. The community partnership program is implemented in madrasah ibtidaiyah because early prevention and understanding of students at the basic level will be better. Community Partnership Services related to early awareness education related to online game viruses were carried out at Madureso Ibtidaiyah madrasah, Kuwarasan District, Kebumen Regency. The dedication is: First, socialization to teachers or asatidz related to online game virus awareness education, amounting to 25 people, Second is providing awareness and understanding of online game viruses by storytelling to grade IV to grade VI students. Third is holding a virus-free online game themed poster competition for students and fourth, making antivirus online game slogans for students. The hope is, with this community service dedication, Ibtidaiyah Madureso, Kuwarasan District, Kebumen Regency will be completely free from student behavior that leads from online game addiction.
\end{abstract}

Keywords: online game; community partnership dedication; madrasah ibtidaiyah muhammadiyah madureso kuwarasan kebumen

\section{PENDAHULUAN}

Salah satu virus yang merusak generasi muda di masa mendatang namun sedang banyak digandrungi oleh kaum anak dan remaja adalah virus game online. Game online itu sendiri adalah permainan di dunia maya yang menampilkan permainan dalam bentuk virtual seperti pada video game. Salah satu keunggulan dari game online tersebut jika dibandingkan dengan jenis permainan video game yang biasa adalah pemain dapat memainkan permainan ini dengan siapapun 
tanpa dibatasi oleh sekat geografis. Menurut artikel yang disampaikan oleh Fakultas Kedokteran Universitas Indonesia dijelaskan bahwa jumlah pecandu game online di Indonesia diduga tertinggi di Asia. Oleh karenanya pemerintah Indonesia diharapkan memiliki kebijakan nasional untuk mengantisipasi dampak adiksi game online demi melindungi kualitas sumber daya manusia di masa depan.

Data lain ditunjukkan oleh Newzoo; The destination for games market insights pada 2019, yang menyatakan bahwa Indonesia berada pada peringkat ke 17 dunia sebagai pengguna game mobile terbanyak dan menyumbang sebesar USD 624 juta atau setara $\mathrm{Rp} 8,7$ triliun untuk mobile gaming sepanjang tahun 2019 (Kaltim, 2020). Data dari Kementerian Komunikasi dan Informatika Republik Indonesia yang disampaikan oleh Rudiantara dinyatakan bahwa 40 juta orang di Indonesia main game, yang diantaranya adalah anak-anak yang masih muda belia, dan kaum remaja, yang apabila kecanduan dapat menyebabkan gangguan secara psikis dan fisik kepada anak-remaja (Kamaliah, 2019).

Hasil pengabdian dari King \& Delfabbro (2018) mnyatakan bahwa kecanduan video game dan game online memberikan dampak negatif dan berbahaya bagi anak dan kaum remaja, yang meliputi ; dari aspek kesehatan, aspek psikologis, aspek akademik, aspek sosial dan aspek keuangan. Dijelaskan secara luas oleh Novrialdy (2019) bahwa dari aspek kesehatan mengarah pada kurang tidur, kurang aktivitas fisik karena berpusat hanya pada game, kurang makan. Dari aspek Psikologis ditunjukkan dengan mudahnya emosional, berperilaku kriminal, kata-kata kotor, mudah tersinggung. Aspek akademik ditunjukkan dengan malas belajar, malam membaca, enggan sekolah, dan berfokus pada kesenangan di depan game online dan video game (Jeong \& Kim, 2011). Aspek lainnya adalah aspek sosial yang ditunjukkan dengan anti sosial, malas bergaul, malas berinteraksi dengan orang, atau jika berinteraksi tetapi sering membuat keributan. Sedangkan aspek keuangan adalah ditunjukkan dengan mudahnya meminta uang pada orang tua, bahkan mencuri, demi untuk main game online (Kowert, Domahidi, \& Quandt, 2014).

Karena sebegitu membahayakannya, perlu program-program pencegahan dan penyadaran akan bahayanya virus game online oleh berbagai pihak, terutama keluarga dan sekolah sebagai lembaga terdekat dengan anak dan remaja. Keluarga adalah tempat pertama untuk membentuk mental dan kepribadian, sehingga anak tidak menjadi anak yang manipulatif dimana anak tersebut mampu menjaga diri dari pengaruh buruk jebakan digital (Rahmatullah, 2017). Selain keluarga, sekolah merupakan tempat yang sangat penting terkait dengan penyadaran dan pencegahan virus game online. Namun pencegahan di sekolah masih sangat minim, hal tersebut selaras dengan hasil pengabdian Kowert, Domahidi, Festl, et al., (2014) yang menyatakan bahwa edukasi penyadaran untuk tidak larut dalam dunia game online kepada peserta didik, masih sangat minim. Bahkan terkadang dalam satu tahun pembelajaran pun sekolah tidak pernah mengadakannya. Idealnya pihak sekolah bersama dengan pihak KPAI (Komisi Perlindungan Anak Indonesia) mengadakan sosialisasi terkait penyadaran kepada peserta didik agar tidak terinfeksi virus game online.

Berdasarkan pada realitas di atas, maka dalam hal ini pengabdi mengamati bahwa pada tataran Sekolah Dasar atau Madrasah Ibtidaiyah sangat perlu untuk aktif diadakan sosialisasi yang sifatnya intens. Hal ini dikarenakan masa Sekolah Dasar atau Madrasah Ibtidaiyah menjadi "dasar penanaman iklim positif serta pikiran positif" yang harapannya, laju perjalanannya menuju remaja dan dewasa akan tetap berada pada jalur yang sesuai aturan positif. Berangkat dari problem di atas, pengabdi bermaksud mengadakan Pengabdian Kemitraan Masarakat (PKM) di Sekolah/Madrasah Dasar, terkait dengan sosialisasi serta berbagai program pencegahan dini virus game online kepada anak-anak yang masih belia. Harapannya, dengan diadakannya program kemitraan ini dapat memberikan pencegahan dini kepada anak-anak untuk tidak main game online, atau apabila sudah ada yang main game online mereka menyudahinya.

Salah satu Madrasah Ibtidaiyah yang layak untuk mendapatkan pemahaman, pencerahan, serta pemberian edukasi terkait virus game online kepada anak-anaknya yang jumlahnya 400 lebih adalah Madrasah Ibtidaiyah Muhammadiyah Madureso Kebumen. Ada beberapa faktor mengapa MI Muhamamdiyah Madureso Kebumen ini perlu mendapatkan sosialisasi serta aplikasi berbagai kegiatan dan program pencegahan terhadap virus game online, yaitu ;

1. Tidak pernah adanya program sosalisasi dan berbagai program lainnya terkait anti virus game online kepada para peserta didiknya. Hal ini tentu "mengkhawatirkan" karena terkadang anak lebih aktif di luar sekolah dan lebih banyak di luar sekolah, yang apapun bisa saja dilakukan oleh anak termasuk permainan game online tanpa 
sepengetahuan guru dan orang tuanya. Dengan jumlah anak MI Madureso yang sebegitu banyaknya, tentu pengawasan kepada mereka minim tatkala di rumah, sehingga apabila tidak ada pencegahan dini dan sosialiasasi program anti virus game online, dikhawatirkan anak akan terus larut pada dunia game online.

2. Tidak pernah adanya sosialiasasi dan pengenalan lebih lanjut terkait pencegahan anak atas game online kepada para dewan guru, sehingga mereka tidak begitu paham bagaimana cara mengatasi anak-anak yang kecanduan game online. Demikian pula para guru tidak begitu mengerti bagaimana mencegah anak-anak untuk tidak aktif dalam dunia game online. Harapannya dengan adanya program kemitraan masyarakat anti virus game online tersebut,guru akan memahami dengan baik bagaimana upaya mencegah sejak dini agar anak didiknya bebas dari virus game online. Mereka juga paham bagaimana mengatasi anak-anak yang kecanduan game online.

3. Tidak ada slogan-slogan di area madrasah yang dapat mengingatkan anak-anak untuk menghidari game online. Madrasah belum membudayakan sosialisasi bergambar anti virus game online kepada anak-anak melalui poster atau banner-banner yang mengarah pada "anti virus game online". Padahal yang demikian sangatlah penting bagi siswa didik

Semua kondisi di atas diakui oleh Ibu Kepala Madrasah yakni Ibu Nurchaenah, M.Pd, yang menyatakan bahwa:

"Memang di MI Muhammadiyah Madureso Kebumen, minim kegiatan atau program berbasis anti virus game online. Selama ini yang dikedepankan adalah bagaimana memperbaiki akhlak dan moralitas anak didik, sehingga harapannya laju perjalanan ank-anak lebih tertata, dan mampu meninggalkan hal-hal buruk dalam keseharian. Namun demikian sejatinya sangat penting adanya sosialisasi dan program-program berbasis anti virus game online ini, sehingga anak akan terjaga dan terlindungi dari sikap buruk dalam keseharian." (Observasi dan Wawancara dengan Ibu Nurchaenah, M.Pd, 20 Desember 2020).

Pernyataan Ibu Kepala Madrasah di atas dikuatkan dengan pernyataan Waka OSIS di MI Madureso lbu Haryanti, S.Pd yang menyatakan bahwa :

"MI Muhammadiyah Madureso belum pernah mengadakan sosialisasi kepada anak-anak dan guru terkait anti virus game online. Padahal sejatinya kegiatan tersebut sangat penting sebagai bentuk pengingat dan penceraha kepada mereka, agar tidak bertindak yang melampaui batas." (Observasi dan Wawancara dengan Ibu Haryanti S.Pd, 20 Desember 2020).

Berangkat dari apa yang disampaikan oleh stakeholder MI Muhammadiyah Madureso Kebumen, maka pengabdi akan berupaya lebih lanjut untuk mengadakan Program Kegiatan Kemitraan Masyarakat di Madrasah Ibtidaiyah tersebut, agar tercipta madrasah-madrasah sehat yang anti virus game online, yang nantinya bisa dijadikan role model bagi sekolah atau madrasah lainnya untuk menerapkan hal yang sama dengan MI Muhamadiyah Madureso Kebumen.

Berdasarkan hasil observasi di lapangan dan wawancara langsung dengan pihak MI Muhammadiyah Madureso Kebumen, maka dapatlah diketahui permasalahan yang dialami oleh mitra, yang antara lain adalah :

1. Belum adanya kegiatan berbasis anti virus game online di Madrasah Ibtidaiyah Madureso Kebumen. Hal ini terjadi dikarenakan belum terfikirnya "kegiatan tersebut" oleh pihak Madrasah.

2. Masih minimnya kewaspadaan diri di lingkungan Madrasah terkait game online ini. Asumsi yang dipegang oleh pihak Madrasah adalah "bahwa di sekolah tidak ada yang aktif bermain game online", padahal yang demikian justru membahayakan, karena sifatnya "melenakan".

3. Masih belum adanya slogan-slogan yang menunjukkan edukasi sadar virus game online di kawasan madrasah.

4. Belum adanya gerakan anti virus game online yang disuarakan oleh pihak yayasan atau komite, di madrasah.

\section{METODE}

Metode yang digunakan dalam pengabdian masyarakat ini adalah dengan metode sosialisasi, penyuluhan serta aksi dengan pendekatan yang diselaraskan dengan umur siswa didik, yakni menggunakan system cerita dan dongeng, dengan harapan lebih mengena kepada siswa didik, daripada dengan sistem seminar atau workhshop, yang tentu saja tidak sesuai dengan umur anak (Rahmatullah \& Azhar, 2020). Aksi yang lain adalah dengan metode lomba melukis, dengan tema yang berkaitan dengan bebas virus game online. Pelaksanaan kegiatan yang sudah 
direncanakan diatas adalah bulan Desember 2020 sampai dengan bulan Januari 2021.

Berkaitan dengan hal tersebut, ada beberapa tahapan yang sudah peneliti laksanakan dan akan dilaksanakan, yang antara lain adalah :

1. Tahapan Pertama, Tahapan observasi langsung dan Proses Identifikasi Masalah di Lapangan

Dalam hal ini peneliti sebelumnya melakukan observasi langsung ke Madrasah Ibtidaiyah Madureso Kebumen dan tidak hanya sekali, namun beberapa kali. Selama observasi memang tidak dijumpai slogan, pamflet dan poster yang berkaitan dengan anti virus game online di sekitar madrasah. Di sisi lain memang hasil wawanacara menyatakan tidak adanya kegiatan-kegiatan yang menunjukkan gerakan bebas anti virus game online. Berangkat dari kondisi real tersebut itulah, yang pada akhirnya menggerakkan hati peneliti untuk melakukan pengabdian kemitraan masyrakat yang berkaitan dengan gerakan edukasi sadar virus anti game online.

2. Tahapan Kedua, Tahapan Penanganan Lebih Lanjut di Madrasah

Setelah mendapatkan hasil nyata di lokasi Pengabadian, dengan data-data konkreat, maka langkah selanjutnya adalah melakukan penanganan yang lebih lanajut di madrasah tersebut, berkaitan dengan bagaimana upaya untuk memberikan pendidikan, pencerahan dan pemahaman atas bahayanya virus game online, serta bagaimana upaya menjauhi hal-hal yang berkaitan dengan virus game online kepada para peserta didik yang masih belia.

3. Tahapan Ketiga, Tahapan Evaluasi Kegiatan

Tahapan ketiga adalah tahapan evaluasi atas segala upaya dalam menangani dan mencegah di madrasah dari virus game online kepada para peserta didik. Dengan adanya evaluasi ini harapannya akan diketahui mana yang harus diperbaiki dan mana yang harus terus dikembangkan dengan baik. Sehingga nantinya berbagai bentuk pencegahan tetap maksimal, dan para peserta didik benar-benar aman dari virus game online baik di dalam maupun di luar madrasah.

Pada pengabdian masyarakat ini yang menjadi objeknya adalah para guru dan karyawan para dewan asatidz/guru yang berjumlah 25 orang, hal ini karena mereka adalah para penggerak dan garda depan di madrasah, sehingga memerlukan banyak pengetahuan untuk menangani anak-anak dari virus game online. Selain itu adalah yang dikedepankan adalah para peseta didik, yang nantinya difokuskan kepada para peserta didik kelas V dan VI di MI Muhammadiyah Madureso. Mengapa kelas V dan VI, karena mereka sudah lebih nalar, dan lebih bisa memahami antara yang baik dan tidak baik, dan bisa diajak diskusi lebih lanjut.

\section{HASIL DAN PEMBAHASAN \\ Sejarah Singkat Madrasah}

Madrasah Ibtidaiyah Muhammadiyah Madureso Kec. Kuwarasan Kebumen mempunyai sejarah perkembangan yang cukup panjang dan unik. Madrasah ini juga sudah melahirkan banyak lulusan yang mempunyai peran yang cukup besar dalam kehidupan bermasyarakat maupun dunia pendidikan.

Madrasah Ibtidaiyah Muhammadiyah Madureso Kec. Kuwarasan Kebumen adalah sebuah madrasah yang didirikan oleh tokoh masyarakat yang juga seorang guru bernama Bapak Darsan (Almarhum) pada tahun 1960 dan juga didukung oleh tokoh masyarakat dan tokoh agama Desa Madureso. Awalnya, pembelajaran berlangsung di rumah-rumah penduduk dan lama kelamaan dengan dukungan para donatur, mendirikan ruang kelas di sebelah utara jalan.

Dari awal pendirian sampai sekarang, MI Muhammadiyah Madureso mampu menjadi madrasah pilihan masyarakat, bahkan 10 tahun terakhir, mulai sekitar tahun 2010 siswanya tidak hanya dari berasal dari desa Madureso tetapi mulai di kenal oleh tetangga desa, seperti: Desa Lemahduwur, Mangli, Kuwarasan, Gumawang, Gunung Mujil, Gandusari, Ori. Dan 3 tahun terakhir, sekitar tahun 2017 merambah hingga 5 Kecamatan, yaitu: Kecamatan. Kuwarasan, Puring, Adimulyo, Buayan dan Gombong. Seperti Desa Jatimulyo, Sidomukti Sembir, Sekarteja, Semanding, Patemon, Kemukus, Karangsari, Kuwaru, Banjareja, waluyorejo, Sidobunder, Sidodadi, Mergosono, Nogoraji, Geblug, Rangka, Adiwarno, Karangbolong, Rogodadi, Sidomukti, Kamulyan, Serut, Pondokgebangsari, Harjodowo. Pada Tahun Pelajaran 2020/2021 hasil pemetaaan berdasarkan wilayah domisili siswa, berasal dari 42 desa dari 5 kecamatan, yaitu: Kuwarasan, Adimulyo, Gombong, Buayan dan Puring.

\section{Visi Madrasah}

Dalam merumuskan visi, pihak-pihak terkait (stakeholders) melakukan musyawarah sehingga visi tersebut benar-benar mewakili aspirasi semua pihak yang terkait. Harapannya, semua pihak yang terkait dalam kegiatan pembelajaran (guru, karyawan, peserta didik, 
dan wali murid) benar-benar menyadari visi tersebut untuk selanjutnya memegang komitmen terhadap visi yang telah disepakati bersama.

Sejalan dengan tujuan dan harapan tersebut, pada tanggal 2 Juli 2019 berdasarkan musyawarah ditetapkan Visi Madrasah Ibtidaiyah Muhammadiyah Madureso Kecamatan Kuwarasan sebagai berikut:

"Terwujudnya Peserta Didik yang Taqwa, Cerdas dan Berahlakul Karimah"

a) Indikator Visi:

1. Siswa dapat melaksanakan salat lima waktu dengan benar

2. Siswa berprestasi di bidang akademik dan non akademik

3. Siswa menghormati kepada yang lebih tua dan menyanyangi yang lebih muda

b) Misi Madrasah

1. Membiasakan peserta didik untuk melaksanakan ibadah harian

2. Membiasakan peserta didik untuk terampil membaca al Qur'an, memahami dan mengamalkannya.

3. Melaksanakan pembelajaran PAKEM

4. Menciptakan budaya gemar membac

5. Menumbuhkan budaya kompetitif (persaingan sehat)

6. Mengembangkan bakat minat peserta didik melalui program ekstrakurikuler

7. Membudayakan senyum, sapa, salam dan magic word (tolong, terima kasih, maaf) Dalam rangka mewujudkan misi tersebut, Madrasah berusaha menerapkan peraturan yang ketat sesuai dengan kedudukan masingmasing dan menjalin komunikasi yang baik untuk menjamin hubungan kerja yang harmonis.

\section{Tujuan Madrasah}

1. Melalui hafalan Juz 'Amma setiap pagi, siswa lancar membaca Al Qur'an dan mengamalkan dalam kehidupan sehari-hari

2. Melalui pembelajaran Pakem, prestasi siswa meningkat, mandiri dan mampu mengatasi masalah

3. Dengan membiasakan membaca, siswa memiliki wawasan yang luas

4. Dengan mengikuti berbagai even lomba, tercipta persaingan sehat

5. Dengan mengembangkan bakat minat peserta didik melalui program ekstrakurikuler, siswa dapat berkembang secara masksimal sesuai bakat dan minat di kemudian hari

6. Dengan Membudayakan senyum, sapa, salam dan magic word (tolong, terima kasih, maaf), siswa mempunyai akhlak yang muliadan bisa menjadi teladan bagi orang lain

\section{Target Madrasah}

1. Target Lulusan

a) Siswa lulus dari MI Muhammadiyah Madureso hafal juz 30

b) Siswa MI Muhammadiyah Madureso dapat Membaca al Qur'an dengan tartil maksimal di kelas 3

c) Siswa MI Muhammadiyah Madureso terbiasa dan disiplin dalam menegakkan shalat 5 waktu

d) Siswa MI Muhammadiyah Madureso terbiasa menutup aurat jika keluar rumah sebagai bentuk ketaaatan pada Alloh

e) Siswa MI Muhammadiyah Madureso terbiasa salat duha dan berdoa setelahnya

f) Siswa MI Muhammadiyah Madureso mempunyai akhlak:

g) Mentaati perintah guru dan orang tua selama perintah itu tidak melanggar syariat Alloh dan sunnah RosulNya

h) Terbiasa meminta maaf jika salah, mengucap terimakasih sebagai bentuk rasa syukur dan mengucap kata 'tolong' jika bermaksud meminta bantuan orang lain

i) Mencintai alam lingkungannya dengan cara merawatnya dan tidak merusaknya, membuang sampah di tempatnya.

2. Target Lembaga

MI Muhammadiyah Madureso mempunyai target untuk 1 tahun yang akan datang:

a) Menjadi madrasah pilihan masyarakat di 5 kecamatan: Kuwarasan, Puring, Buayan, Gombong dan Adimulyo. Dari kondisi sekarang 40 desa dari 5 kecamatan menjadi 45 desa

b) Mempunyai siswa berjumlah 450 siswa di tahun 2021.Posisi sekarang 408 siswa

c) Mempunyai lahan seluas $3.500 \mathrm{~m} 2$, perluasan ke timur dan utara. Posisi sekarang $2.946 \mathrm{~m} 2$

d) Mempunyai gedung yang representatif dengan konsep one stop service: madrasah sebagai tempat mencari ilmu dan pembentukan akhlak, tempat ibadah dan menjadi pusat kajian keilmuan dan mempunyai pusat bisnis dalam satu kawasan madrasah. Tempat mencari ilmu sudah, tempat ibadah dan tempat kajian keilmuan belum maksimal karena belum 
mempunyai mushola dan gedung sebagai tempat kajian ilmu. Toko baju perlu dikembangkan lagi.

e) Mempunyai tenaga pengajar yang handal: sholeh yang bisa mensholehkan umat, cerdas dan mencerdaskan umat, kreatif yang bisa menginspirasi umat.

f) Lulusan MI Muhammadiyah Madureso hafal 3 juz Alqur'an. Posisi sekarang 1 juz saat lulus

g) Pelaksanaan pembelajaran ramah anak dan ramah lingkungan, baik di dalam kegiatan intra maupun kegiatan ekstra kurikuler

\section{Mencermati Virus Game Online di Madrasah Ibtidaiyah Muhammadiyah Madureso Kecamatan Kuwarasan}

Madrasah Ibtidaiyah Muhammadiyah Madureso Kecamatan Kuwarasan Kebumen adalah madrasah berbasis integrasi pengetahuan, yang memadukan antara pengetahuan umum dan pengetahuan agama, yang tidak hanya teorisasi tetapi kaya dengan aplikasi nyata bagi para peserta didik. Para peserta didik belajar bagaimana memperkaya diri dengan kecerdasan akal, kecerdasan jiwa, serta kecerdasan spiritual, satu paket yang menjadikan para lulusannya memiliki peradaban keilmuan dan akhlakul karimah yang kuat. Hal ini dapat dilihat dari para alumninya yang memang berkarakter dan memiliki wawasan pengetahuan luas. Hal ini sesuai dengan pernyataan Pengawas Madrasah yang menyatakan bahwa :

"Proses pendidikan, pengasuhan, pembelajaran yang ada di Madrasah Ibtidaiyah Muhammadiyah Madureso Kecamatan Kuwarasan Kebumen sangat baik, hal yang mengesankan adalah pada pembumisasian akhlak, moral dan etika serta spiritual kepada para peserta didik. Sehingga iklim positif terbangun dengan baik pada madrasah tersebut." (Wawancara dengan Bu Hj. Wuryani, M.Pd, pengawas madrasah, 5 Februari 2021).

Madrasah Ibtidaiyah Muhammadiyah Madureso Kecamatan Kuwarasan Kebumen ini dibangun sejak awal oleh para pendiri dengan beberapa alasan kuat, yakni :

a. Untuk memuliakan masyarakat, dengan pengkayaan peradaban ilmu dan akhlak. Hal ini dikarenakan di sekitar Madrasah Ibtidaiyah tersebut tidak ada sekolah berbasis perpaduan keilmuan. Di sekitar MI Madureso hanya ada beberapa sekolah negeri, yang hanya mengkaji ilmu umum dan sedikit ilmu agama. Sehingga masyarakat berkeinginan untuk mengadakan sekolah berbasis umum dan agama, sehingga akan membantu menciptakan peradaban akhlak yang kuat di masyarakat sekitar. Terbukti setelah didirikannya Madrasah Ibtidaiyah tersebut, madrasah ini setiap tahunnya sudah diserbu serta banyak masyarakat yang mengantri untuk masuk ke madrasah tersebut.

b. Selain berfungsi untuk membangun peradaban keilmuan dan akhlak, dibangunnya MI Muhammadiyah Madureso ini adalah untuk menunjukkan bahwa madrasah bukan pinggiran, sekolah madrasah juga bisa berprestasi unggulan, sekolah di madrasah juga bisa menjadi orang. Hal ini karena image masyarakat selama ini- yang terbangun adalah madrasah sekolah ndeso, madrasah sekolah yang ketinggalan zaman, madrasah sekolah yang hanya belajar agama, sehingga tidak bisa berkembang, madrasah adalah sekolah tidak bonafit dan sebagainya. Sehingga dengan alasan inilah dibangunnya MI Muhammadiyah Madureso Kebumen, yang pada akhirnya bisa menujukkan kepada masyarakat luas bahwa sekolah di Madrasah adalah kebanggaan, sekolah di madrasah tidaklah kalah dengan sekolah yang unggulan lainnya. Bahkan nilai plus dari sekolah di madrasah adalah agama, dan akhlak.

c. MI Muhammadiyah Madureso dibangun dengan alasan kuat untuk menciptakan desa yang berbasis spiritual, yang menjadi kebanggaan desa. Dengan hadirnya MI Muhammadiyah Madureso Kuwarasan Kebumen ini akan tercipta suasana yang harmonis penuh rahmat Allah SWT, dan tercipta desa yang berbasis pelaksanaan agama yang kuat.

Berbagai upaya dan usaha dilakukan oleh MI Muhammadiyah Madureso Kuwarasan Kebumen untuk menciptakan Madrasah berbasis spiritual, kuat karakter dan berpengetahuan luas serta bebas. Hal ini dapat dilihat dengan berbagai kegiatan dan pembudayaan karakter yang diterapkan seharihari, sehingga membekas bagi para peserta didik, di antaranya adalah :

a. Pembudayaan salam di seluruh isi madrasah, ketika berjumpa dengan siapapun peserta didik dan seluruh warga madrasah dikondisikan untuk aktif menyemaikan salam kebaikan dan kebajikan.

b. Pembudayaan shalat yang tidak hanya sekedar ritual ibadah, tetapi sudah mulai dilatih pemaknaan shalat, dan mengajak para peserta didik menjiwai perilaku shalat. 
c. Membudayakan perilaku sehat jiwa dan sehat jasadiyah kepada para siswa didik

d. Pembudayaan kepada para peserta didik untuk berpikir sehat, dengan banyaknya program kegiatan berbasis akal sehat.

Salah satu hal yang tidak dan atau belum terpikirkan dari pembudayaan karakter di Madrasah Ibtidaiyah Madureso Kuwarasan Kebumen adalah tentang perilaku main video game dan game online oleh para peserta didik. Perilaku ini belum mendapatkan tempat atau posisi tersendiri oleh Pihak Madrasah. Artinya, selama ini pihak madrasah belum atau tidak memikirkan ke arah penanganan virus game online. Kerena selama ini para peserta didiknya, menurut Kepala Madrasah MI Muhammadiyah Madureso tidak menunjukkan perilaku berlebihan dalam permainan video game ataupun game online. Meski sejatiya pihak madrasah hanya bersifat "menduga" atau "mengira-ira" bahwa di sekolah tidak ada masalah, tetapi mereka belum menelusuri bagaimana perilaku siswa didik di luar madrasah.

"Anak-anak jika di sekolah tidak menunjukkan gejala aktif main game online, dan selama ini juga tidak ada laporan terkait dengan penyakit game online atau video game, tetapi memang terus terang, untuk penelusuran di rumah masing-masing ini pihak madrasah belum lakukan. Terkait bagaimana perilaku anak-anak di rumah, apakah aktif main game atau tidak, ini yang belum menjadi pemikiran serta tindak lanjut. (Wawancara dengan Ibu Nurchaenah, M.Pd Kepala Madrasah, 6 Februari 2021)

Memang salah satu kelemahan yang ada di Madrasah Ibtidaiyyah Madureso Kuwarasan Kebumen adalah tidak tanggap terhadap virus game online kepada para peserta didik. Artinya tingkat sadar akan bahaya virus game online dan video game belum membudaya pada seluruh stake holder di madrasah. Hal ini dapat dilihat dari beberapa indikasi yang ada di madrasah:

a. Tidak pernah dilakukan kegiatan yang mengarah pada sosialisasi sadar virus game online bagi para asatidz dan karyawan apalagi kepada para peserta didik.

b. Tidak pernah ada kegiatan-kegiatan /program yang berbasis anti virus game online baik untuk para asatidz di madrasah maupun untuk peserta didik.

c. Tidak ada poster atau baliho yang memuat sadar virus game online bagi warga Madrasah Ibtidaiyah Madureso Kuwarasan Kebumen d. Tidak adanya kerjasama dengan instansi pemerintahan, swasta atau LSM yang fokus menangani pencegahan virus game online kepada warga sekolah.

e. Tidak adanya lomba-lomba baik internal madrasah atau ekternal yang berkaitan dengan pencegahan virus game online kepada peserta didik.

Berbagai kelemahan yang disadari langsung oleh stake holder Madrasah Ibtidaiyyah Madureso Kuwarasan Kebumen. Ada beberapa faktor pemicu terciptanya minim sadar virus game online di MI Muhammadiyah Madureso Kuwarasan Kebumen, yakni :

a. Faktor mininya kegelisahan para asatidz di Madrasah. Artinya selama ini para asatidz ayem adem dan merasa tidak ada masalah, dan tidak bermasalah, apalagi terkait dengan adanya game online ini. Tidak adanya kegelisahan ini yang kemudian menjadikan madrasah tidak memiliki program atau kegiatan berbasis sadar virus game online bagi peserta didik.

b. Faktor minimnya pengetahuan para asatidz terkait dengan virus game online. Artinya, para asatidz tetap berbaik sangka bahwa virus tersebut tidak akan masuk pada wilayah MI Muhammadiyah Madureso Kuwarasan Kebumen, hal ini yang justru menjadikan kelengahan dan kelenaan sehingga tidak terpikirkan untuk membuat program- program berbasis anti virus game online.

c. Faktor kurangnya update berita terkait bahaya virus game online bagi peserta didik. Para asatidz lebih fokus kepada bagaimana cara mengajar yang baik, dari pada mencari berita-berita tentang bahaya virus game online. Hal ini pada akhirnya menjadikan pihak madrasah tidak membuat kegiatan-kegiatan berbasis anti virus game online.

Berangkat dari permasalahan di atas, maka pengabdi (PKM) berupaya ingin memberikan solusi untuk memberikan sadar virus game online bagi para asatidz dan peserta didik di MI Muhammadiyah Madureso Kuwarasan Kebumen, dengan harapan akan mampu membantu pihak madrasah menjaga dari adanya virus game online yang berbahaya.

\section{Langkah Nyata Pendidikan Sadar Virus Game Online di MI Muhammadiyah Madureso Kuwarasan Kebumen}

Sehubungan dengan realitas di lapangan yang menyatakan bahwa belum adanya pembahasan khusus terkait dengan penanganan dan pendidikan sadar virus game 
online di Madrasah, hal ini menjadikan pihak madrasah berharap besar dengan adanya PKM (Program Kemitraan Masyarakat) ini, akan merubah mindset warga akademik di MI Muhammadiyah Madureso Kuwarasan Kebumen. Oleh karenanya ada beberapa hal yang dilaksanakan oleh Tim PKM LP3M Universitas Muhammadiyah Yogyakarta di MI Muhammadiyah Madureso Kuwarasan Kebumen.

\section{Sosialisasi Kepada Para Guru/Asatidz Terkait Pendidikan Sadar Virus Game Online Sosialisasi yang pertama kali dilaksanakan di Madrasaah Ibtidaiyyah Muhammadiyah Madureso Kuwarasan Kebumen kepada para dewan asatidz/guru, serta para karyawan yang berjumlah 25 orang. Adapun sosialisasi kepada para guru atau asatidz terkait pendidikan sadar virus game online dapat dilihat pada gambar 1 dan gambar 2.}

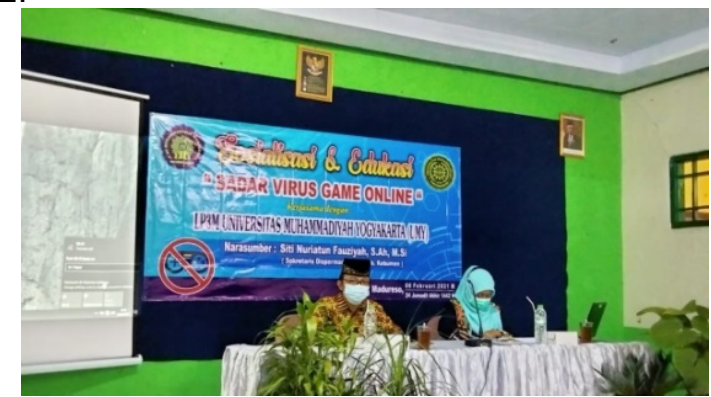

Gambar 1. Sosialisasi kepada guru/asatidz

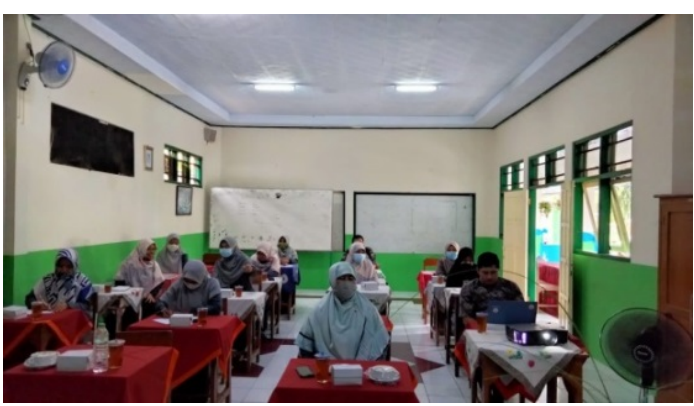

Gambar 2. Sosialisasi kepada guru/asatidz

Dewan asatidz/karyawan menjadi pihak yang pertama kali mendapatkan sosialisasi dikarenakan mereka adalah tonggaknya perilaku di madrasah. Apabila mereka belum dibekali terkait dengan pengetahuan bahayanya game online dan bagaimana pencegahannya, maka para guru dan karyawan tidak akan mampu membentengi para siswa didik untuk tidak "bermain-main" dengan game online. Oleh karenanya "sosialisasi yang sifatnya mendalam" diberlakukan kepada para dewan guru/asatidz dan karyawan, yang difungsikan untuk memperkuat pemahaman diri atas hal-hal yang berkaitan dengan virus game online. Dalam hal ini sosialisasi disampaikan oleh pihak yang berkompeten, yakni Dinas Pemberdayaan Masyarakat dan Desa dan Pemberdayaan Perempuan dan Perlindungan Anak Kabupaten Kebumen (Dispermades P3A). Dengan pembicara adalah Sekretaris Dispermades P3A Kabupaten Kebumen Ibu Siti Nuriatun Fauziyah, SAg, M.Si. Setelah pelaksanaan sosialisasi pendidikan sadar virus game online di MI Muhammadiyah Madureso Kuwarasan Kebumen selesai, dilakukan sesi penyererahan kenang-kenangan dan foto bersama yang dapat dilihat pada gambar 3 dan gambar 4 .

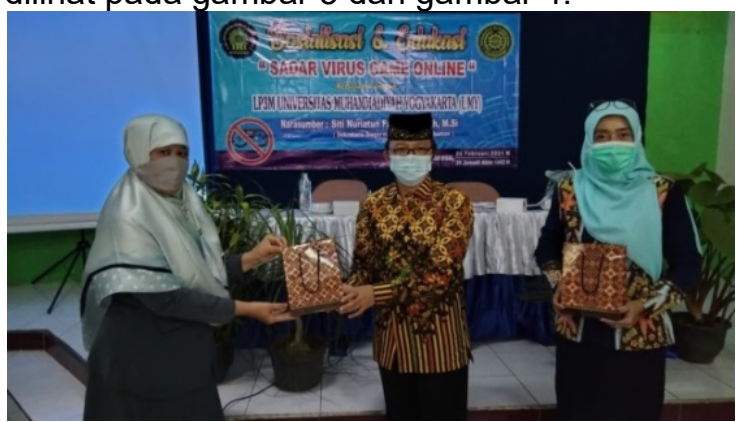

Gambar 3. Pemberian kenang-kenangan

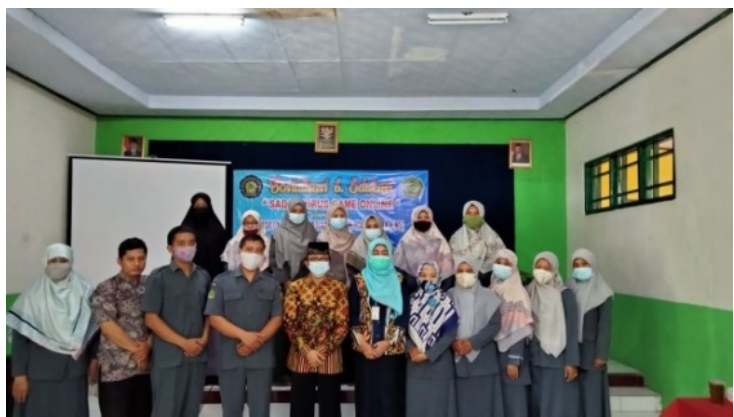

Gambar 4. Foto bersama

Setelah proses sosialisasi kepada para dewan asatidz/guru selesai, tahapan selanjutnya adalah memberikan sosialisasi kepada para siswa Madrasaah Ibtidaiyyah Muhammadiyah Madureso Kuwarasan Kebumen.

\section{Memberi Penyadaran dan Pemahaman Tentang Virus Game Online Dengan Mendongeng kepada Siswa MI Muhammadiyah Madureso Kuwarasan Kebumen}

Salah satu cara untuk memahamkan para peserta didik "kecil" terkait agar tidak bermain game online berlebihan, tidak menggandrungi game online secara berlebihan, dan agar mereka meningkatkan kewaspadaan diri adalah dengan menggunakan gaya bahasa mereka, bukan gaya bahasa orang tua, yakni dengan cara mendongeng dengan tema adalah bebas virus game online bagi peserta didik. Dalam hal ini dongeng diberikan oleh pakar atau ahlinya mendongeng Wilayah Kebumen, yang sudah memiliki jam terbang tinggi yakni Kak' 
Anwar, M.Pd, dengan para peserta adalah peserta didik kelas IV-VI MI Muhammadiyah Madureso Kuwarasan Kebumen. Adapun kegiatan mendongeng dapat dilihat pada gambar 5 .

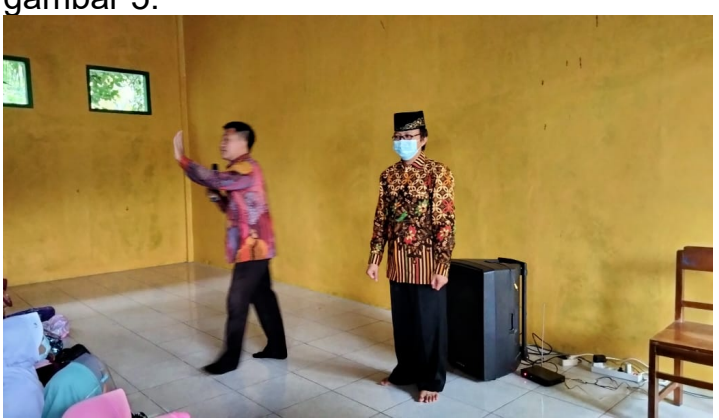

Gambar 5. Mendongeng kepada siswa

Dalam hal ini mengapa diambil kelas IVVI? Karena secara umum yang banyak aktivitas melakukan permainan game adalah kelas tersebut, sehingga kelas inilah yang dimaksimalkan untuk mendapatkan pencegahan dengan cara dongeng. Berikut ini adalah beberapa gambar berkaitan dengan mendongeng (Gambar 6 dan gambar 7):

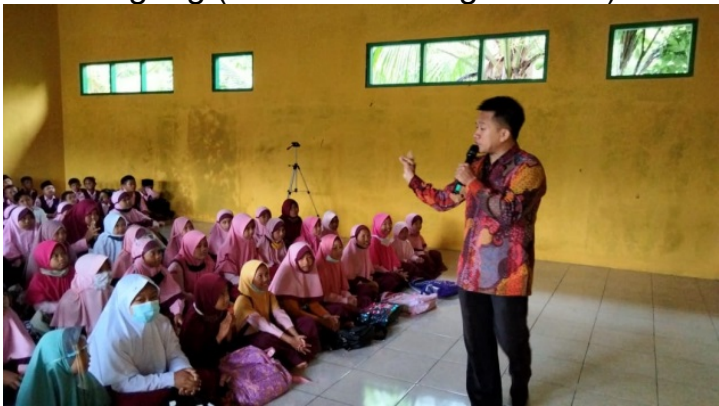

Gambar 6. Mendongeng kepada siswa

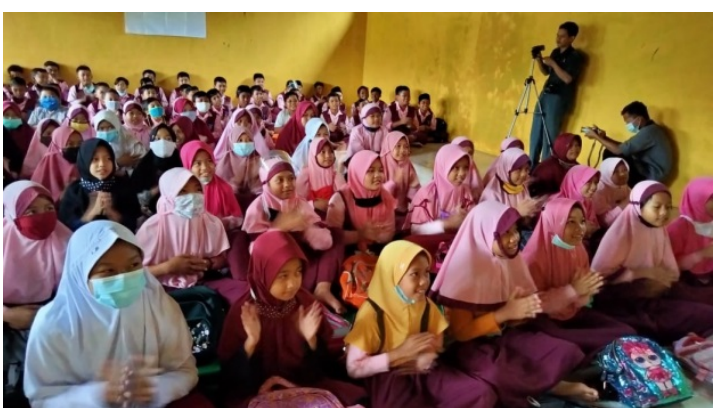

Gambar 7. Siswa mendengarkan dongeng

Dengan media mendongeng ini, diharapkan siswa lebih antusias sehingga dapat dengan mudah dapat menyerap dan memahami apa yang disampaikan oleh pemateri.

\section{Lomba Poster Bertemakan Bebas Virus Game Online bagi Para Peserta Didik di MI Muhammadiyah Madureso Kuwarasan Kebumen}

Cara lain untuk memahamkan para peserta didik tentang bahaya virus game online adalah dengan cara lomba poster yang temanya adalah seputar bahaya game online. Lomba poster ini baru pertama kali digelar oleh pihak madrasah, terutama dengan tema yang berkaitan dengan virus game online tersebut. Tujuan dari lomba poster ini adalah untuk ikut menggiatkan dan "andar beni" para peserta didik sehingga mereka benar-benar semakin mengerti tentang bahayanya virus game online. Lomba ini diikuti oleh para peserta didik dari Kelas V dan VI, yang mana mereka sudah bisa berpikir lebih luas, dirasa sudah semakin beranjak besar sehingga tingkat pemahamannya semakin besar. Berikut beberapa gambar yang menunjukkan pelaksanaan lomba poster bagi para peserta didik (Gambar 8 dan Gambar 9) :

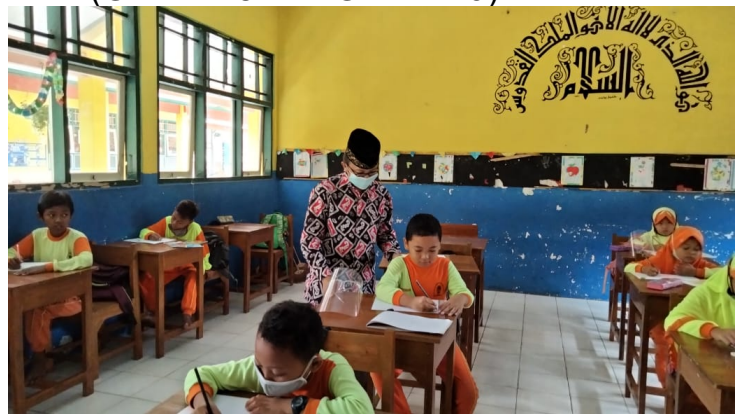

Gambar 8. Pelaksanaan lomba poster

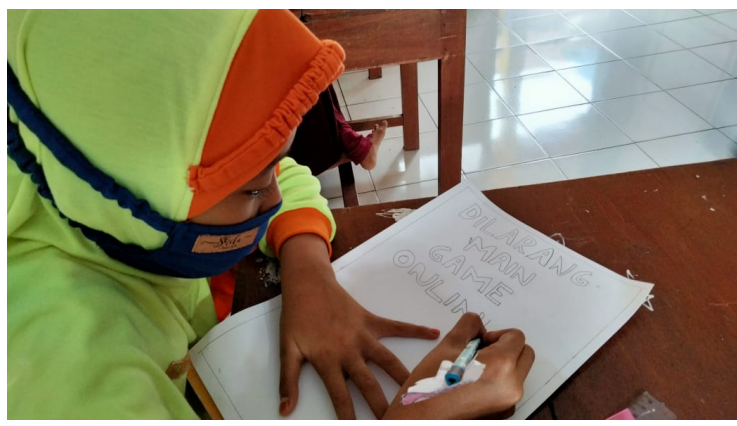

Gambar 9. Siswa membuat poster

Untuk tema utamanya adalah sadar virus game online, namun para peserta dibebaskan berkreasi sekreatif mungkin dengan karya mereka. Dalam lomba poster ini di ambil beberapa juara yang hasil karya mereka dinilai secara obyektif oleh panitia. Berikut beberapa karya dari peserta lomba seperti yang terlihat pada Gambar 10 dan Gambar 11 


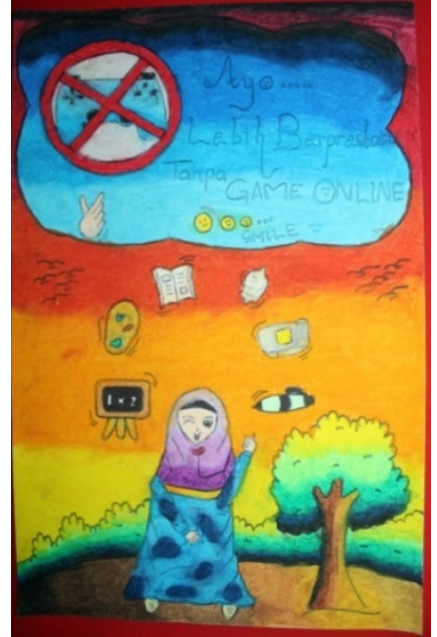

Gambar 10. Poster hasil karya siswa

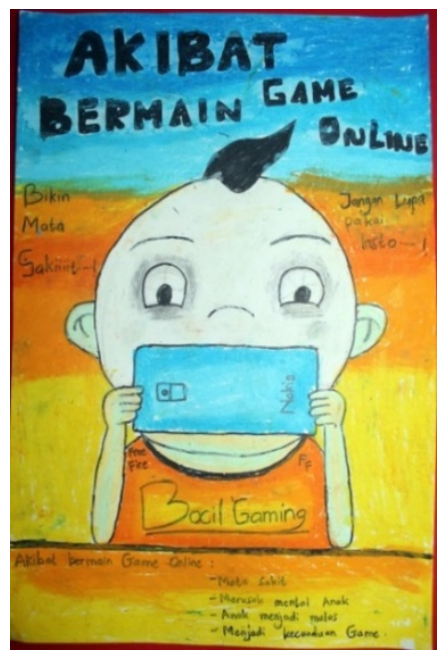

Gambar 11. Poster hasil karya siswa

Membuat Slogan-Slogan Anti Virus Game Onlie untuk bagi Para Peserta Didik di MI Muhammadiyah Madureso Kuwarasan Kebumen

Slogan-slogan anti virus game online menjadi sangat penting untuk dibuat dan disemaikan di lingkungan madrasah. Selama ini pula slogan-slogan tersebut tidak pernah ada dan tidak pernah dimunculkan di lingkungan madrasah. Padahal sejatinya, slogan-slogan tersebut adalah sebagai pengingat bagi para peserta didik yang sifatnya kontinue. Berikut adalah beberapa contoh dari slogan-slogan tersebut (Gambar 12, Gambar 13 dan Gambar 14) :

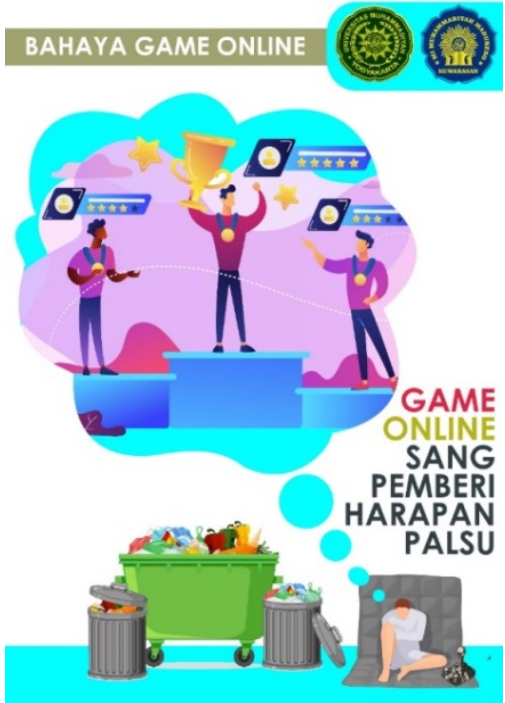

Gambar 12. Poster slogan bebas virus game online

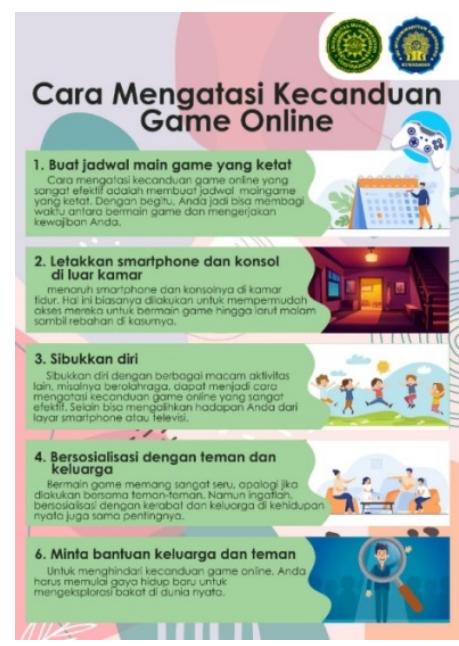

Gambar 13. Poster slogan bebas virus game online

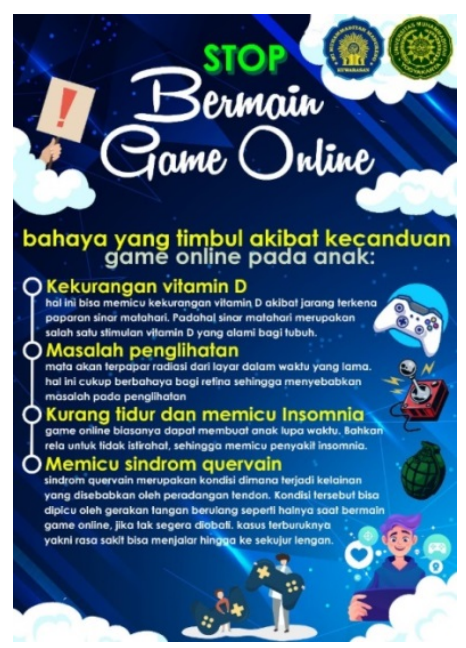

Gambar 14. Poster slogan bebas virus game online 
Dengan adanya slogan-slogan yang tertempel di lingkungan madrasah, secara otomatis akan sering dilihat para peserta didik, dan secara otomatis pula akan masuk ke alam bawah sadar mereka, sehingga geliat untuk membentengi diri dari virus tersebut akan kuat dilaksanakan para peserta didik.

\section{SIMPULAN}

Berdasarkan kegiatan pengabdian yang di laksanakan di Madrasah ibtidaiyah Kec Kuwarasan, Kabupaten kebumen dapat diambil beberapa kesimpulan yaitu belum adanya kegiatan yang dilakukan pihak madrasah mengenai penaganan dini dampak buruk game online menunjukkan bahwa perhatiannya terhadap virus game online kepada peserta didik masih kurang. Artinya selama ini pihak madrasaah belum mengkonsentrasikan kepada penanganan virus game online dengan asumsi karena di madrasah tidak atau belum ada kasus yang menunjukkan perilaku berlebihan oleh peserta didik terhadap game online.

Selain itu, di madrasah tidak/belum ada kegiatan-kegiatan yang fokus kepada pendidikan virus game online kepada para peserta didik. Sehingga kelemahan ini justru akan mengkhawatirkan nasib para perserta didik dan hal ini juga merupakan bentuk kelengahan, yang tidak boleh terus dipertahankan, karena akan menjadi virus yang sesungguhnya bagi para peserta didik, karena tidak ada pantauan dan pencegahan serta pendidikan sadar dini virus game online.

Beberapa kegiatan yang mulai dirintis oleh madrasah sebagai bentuk pendidikan sadar dini virus game online kepada para peserta duidik dan masyarakat akademik di lingkungan madrasah adalah ; Pertama, Sosialisasi Kepada Para Guru/Asatidz Terkait Pendidikan Sadar Virus Game Online, Kedua, Memberi Penyadaran dan Pemahaman Tentang Virus Game Online Dengan Mendongeng kepada Siswa MI Muhammadiyah Madureso Kuwarasan Kebumen, Ketiga, Lomba Poster Bertemakan Bebas Virus Game Online bagi Para Peserta Didik di Ml Muhammadiyah Madureso Kuwarasan Kebumen, Keempat, Membuat Slogan-Slogan Anti Virus Game Online untuk bagi Para Peserta Didik di MI Muhammadiyah Madureso Kuwarasan Kebumen.

\section{DAFTAR RUJUKAN}

FKUI, I. (2019). Jumlah Pecandu Game Online di Indonesia Diduga Tertinggi di Asia. Fakultas Kedokteran Universitas Indonesia.

https://fk.ui.ac.id/infosehat/jumlah- pecandu-game-online-di-indonesiadiduga-tertinggi-di-asia/

Jeong, E. J., \& Kim, D. H. (2011). Social Activities, Self-Efficacy, Game Attitudes, and Game Addiction. Cyberpsychology, Behavior, and Social Networking, 14(4), 213-221.

https://doi.org/10.1089/cyber.2009.028 9

Kaltim, T. (2020). Indonesia Peringkat ke 17 Dunia, Pengguna Game Online Terbanyak, PUBG Mobile Kian Menjamur. Tribun News. https://tribunkaltimtravel.tribunnews.co $\mathrm{m} / 2020 / 07 / 07 /$ indonesia-peringkat-ke17-dunia-pengguna-game-onlineterbanyak-pubg-mobile-kian-menjamur

Kamaliah, A. (2019). Menkominfo: 40 Juta Orang Indonesia Main Game. Inet.Detik.Com.

https://inet.detik.com/games-news/d4705217/menkominfo-40-juta-orangindonesia-main-game

King, D. L., \& Delfabbro, P. H. (2018). Predatory monetization schemes in video games (e.g. 'loot boxes') and internet gaming disorder. Addiction, 113(11), 19671969. https://doi.org/10.1111/add.14286

Kowert, R., Domahidi, E., Festl, R., \& Quandt, T. (2014). Social gaming, lonely life? The impact of digital game play on adolescents' social circles. Computers in Human Behavior, 36, 385-390. https://doi.org/10.1016/j.chb.2014.04.0 03

Kowert, R., Domahidi, E., \& Quandt, T. (2014). The Relationship Between Online Video Game Involvement and GamingRelated Friendships Among Emotionally Sensitive Individuals. Cyberpsychology, Behavior, and Social Networking, 17(7), 447-453. https://doi.org/10.1089/cyber.2013.065 6

Novrialdy, E. (2019). Kecanduan Game Online pada Remaja: Dampak dan Pencegahannya. Buletin Psikologi, 27(2), 148-158. https://doi.org/10.22146/buletinpsikolo gi.47402

Rahmatullah, A. S. (2017). Pendidikan Keluarga Seimbang yang Melekat Sebagai Basis yang Mencerahkan Anak di Era Digital. Cendekia: Journal of Education and Society, 15(2), 211224.

https://doi.org/10.21154/cendekia.v15i 2.1144

Rahmatullah, A. S., \& Azhar, M. (2020). 
Pendidikan Dini Sadar Virus Bullying Di

Sekolah Atau Madrasah. Jurnal

Abdidas, 1(4), 261-276.

https://doi.org/10.31004/abdidas.v1i4.5

6 